\title{
Household food wastage in Britain
}

\author{
BY R. W. WENLOCK, D. H. BUSS AND B. J. DERRY \\ Ministry of Agriculture, Fisheries and Food, London $S W_{\mathrm{I}}$ \\ AND E. J. DIXON \\ Laboratory of the Government Chemist, London SEI
}

(Received 24 May 1979-Accepted 4 July 1979)

\begin{abstract}
1. The total food and drink available for human consumption in the United Kingdom would provide approximately $13 \mathrm{MJ}(3100 \mathrm{kcal}) /$ person per $\mathrm{d}$, while the energy intake recommended for the population is approximately $9.6 \mathrm{MJ}(2300 \mathrm{kcal}) /$ person per d. A proportion of this substantial difference must be due to wastage in the home as well as in catering establishments and during the storage, distribution and processing of food.
\end{abstract}

2. As part of a general investigation of this problem, a representative sample of 1000 British households was asked to collect all the potentially-edible food wasted in their homes during I week, and to keep a record of the food, other than commercial pet food, which they gave to pets and wild birds. A total of 672 households co-operated fully, 338 in summer and 334 in winter. Each food sample received was weighed, and its energy content was determined calorimetrically.

3. Significantly more waste food was collected in summer than in winter, equivalent to $9 \cdot 3 \mathrm{MJ}$ (2220 kcal)/ household per week and 7.1 $\mathrm{MJ}(1700 \mathrm{kcal}) /$ household per week respectively. In terms of energy, cereals, fat and meat wastage predominated, while in terms of weight, milk was more important and fat less so.

4. Considerable quantities of otherwise edible food were also given to pets and birds, accounting on average for a further $2.4 \mathrm{MJ}(570 \mathrm{kcal})$ and $3.0 \mathrm{MJ}(710 \mathrm{kcal}) /$ household per week in summer and winter respectively. The energy content of all food wasted in the home therefore averaged $11 \cdot 7 \mathrm{MJ}(2790 \mathrm{kcal}) /$ household per week in summer and $10.1 \mathrm{MJ}(2410 \mathrm{kcal}) / \mathrm{household}$ per week in winter, equivalent to $0.6 \mathrm{MJ}$ ( $150 \mathrm{kcal}$ ) and $0.5 \mathrm{MJ}$ (1 $30 \mathrm{kcal}) /$ person per $\mathrm{d}$ respectively. This is less than one-quarter of the gap between food supplies and the amount of food thought to be eaten in the UK.

5. Food wastage was significantly influenced by the composition of the family, with adults wasting more in absolute terms than children, and larger households wasting less per person than smaller households. However, with few exceptions, neither income nor geographical region significantly affected the total amount of food wasted in the home.

6. When assessed against the expected usage of food in the home, wastage accounted on average for $6.5 \%$ of the energy intake in summer and $5.4 \%$ in winter.

There was sufficient food in the United Kingdom in 1976 to have provided $12 \cdot 3$ MJ (2940 $\mathrm{kcal})$ to each person each day, and a further $0.7 \mathrm{MJ}(160 \mathrm{kcal})$ was available from alcoholic drinks (Ministry of Agriculture, Fisheries and Food, I978b). These estimates relate to the edible portion of the food made available for human consumption from our farms and from imports, after allowance has been made for exports, non-food usage and any changes in year-end stocks. In contrast, the weighted average physiological requirement of the population for energy, calculated from the intakes recommended by the Department of Health and Social Security (1969) for different categories of people in the United Kingdom was only 9.6-9.8 MJ (2300-2350 kcal)/person per d, the value depending on the relative proportions of men who are sedentary and moderately active. More recent estimates of actual energy intakes, and therefore of energy requirements, suggest that they may now be 5-6\% less than this (Department of Health and Social Security, 1979).

Similar differences between food supplies and requirements have long occurred in most developed countries (FAO, 1952), but the reasons are not well understood. Losses of potentially-edible food are of course inevitable during storage, distribution, processing and cooking, and occur even when food supplies are short (Hollingsworth \& Baines, 1961); nevertheless, little is known about how much of each food is lost at each stage of processing and distribution or in catering establishments or the home. Therefore, as part of a general 
investigation into the problem in this country by the Ministry of Agriculture, Fisheries and Food (Singer \& Smart, 1978), a study of one of the important contributory factors, food wastage in the home, was undertaken.

Since prewar studies (Cathcart \& Murray, 1939) showed that 1-3\% of food was wasted in the home in Britain, there has been little work on this aspect of food loss. Some household studies were attempted in the United States (Adelson et al. 196I ; Adelson et al. 1963) which indicated that between 7 and $10 \%$ of domestic food (in energy terms) was thrown away, given to pets, or otherwise used for non-food purposes. Fats and oils accounted for between 70 and $80 \%$ of this loss. It was thought that these figures underestimated household wastage, largely because any implication that discarded food is 'wasted' could affect accurate reporting of the food thrown away or else change discard patterns. It was also noted that studies of this kind are very difficult because the intensive questioning which is necessary and the period of time involved result in poor co-operation by the housewives. Another, nonreactive, approach was therefore tried in Tucson, Arizona, where the waste food in garbage cans was studied (Harrison et al. 1975). This showed that on average approximately $10 \%$ by weight of the food which entered the home (estimated from discarded food wrappers) was wasted. This would not, however, have included food given to pets or washed down sinks or through garbage disposal units. In the United States, the General Accounting Office ( 1977 ) reported to Congress that no other evidence on the magnitude of food wastage in the home existed.

More recently, a study on twenty-five households in South London showed that approximately $4 \%$ of the available food was wasted (Dowler, 1977). We also carried out a preliminary study on fifty-two households of civil servants in Southern England to assess the magnitude of domestic waste and to gain experience in measuring this in the home (Wenlock \& Buss, 1977). Approximately $5 \%$ of the food energy and rather more of the fat which was estimated to have been used during I week was found to have been discarded. Significant amounts of food were also given to pets in some homes, which, when averaged across the whole sample, raised wastage to $6 \%$. Wastage appeared to be related to household size with each person contributing, in effect, approximately $400 \mathrm{~kJ}(95 \mathrm{kcal}) / \mathrm{d}$.

Using experience gained from these studies, we have now carried out a survey of food wastage in a random sample of 1000 households throughout the whole of Britain. Because food purchases fluctuate with season (Ministry of Agriculture, Fisheries and Food, 1978a) and because food wastage was also likely to have a seasonal pattern, half of the survey was carried out in June and July 1976 and the remaining half in February and March 1977. This study, and the results obtained from it, are now presented herein.

\section{METHODS}

The selection of the sample and all contacts with households, the interviews, and the collection of wasted food were carried out under contract to the Ministry by Research Services Ltd, Harrow Road, Wembley, Middlesex.

\section{Sample design}

The sample was designed to be as representative of the household population of Great Britain as possible, except that for operational reasons households in the sparsely-populated region north of the Caledonian Canal were excluded.

A three-stage stratified random sampling scheme was used. The first stage involved the selection of Local Authority areas; the second, selection of polling districts within these areas; and the third, selection of addresses within the polling districts. All Local Authority areas within each of the Registrar Generals' eleven planning regions were first stratified into conurbations, non-conurbation urban areas and rural areas. Conurbations were further 
Table I. Local Authority areas sampled during the survey

\begin{tabular}{|c|c|c|c|}
\hline Region & Local Authority* & Region & Local Authority* \\
\hline \multicolumn{4}{|l|}{ England } \\
\hline & $\begin{array}{l}\text { Whitley Bay MB } \\
\text { Teesside CB } \\
\text { Workington MB }\end{array}$ & South West & $\begin{array}{l}\text { Bristol MB } \\
\text { Weymouth and } \\
\text { Melcombe Regis MB } \\
\text { Sodbury RD }\end{array}$ \\
\hline \multirow[t]{2}{*}{ Yorks and Humberside } & $\begin{array}{l}\text { Leeds CB } \\
\text { Pudsey MB }\end{array}$ & & Langport RD \\
\hline & $\begin{array}{l}\text { Kingston upon Hull CB } \\
\text { Conisbrough UD }\end{array}$ & South East & $\begin{array}{l}\text { Worthing MB } \\
\text { Reading CB } \\
\text { Banstead UD }\end{array}$ \\
\hline North West & $\begin{array}{l}\text { Wirral UD } \\
\text { Manchester CB } \\
\text { Royton UD } \\
\text { St Helens CB } \\
\text { Leyland UD } \\
\text { Nantwich RD }\end{array}$ & & $\begin{array}{l}\text { Burgess Hill UD } \\
\text { Eastbourne CB } \\
\text { Alton UD } \\
\text { Godstone RD } \\
\text { Bradfield RD } \\
\text { Malling RD }\end{array}$ \\
\hline West Midlands & $\begin{array}{l}\text { Wolverhampton CB } \\
\text { Birmingham CB } \\
\text { Warley CB } \\
\text { Rugby MB } \\
\text { Tutbury RD }\end{array}$ & Greater London & $\begin{array}{l}\text { Camden LB } \\
\text { Barking LB } \\
\text { Harrow LB } \\
\text { Enfield LB } \\
\text { Havering LB } \\
\text { Haringey LB }\end{array}$ \\
\hline \multirow[t]{2}{*}{ East Midlands } & $\begin{array}{l}\text { Leicester CB } \\
\text { Chesterfield MB }\end{array}$ & & Hammersmith LB \\
\hline & Southwell RD & Wales & $\begin{array}{l}\text { Cardiff CB } \\
\text { Merthyr Tydfil CB }\end{array}$ \\
\hline East Anglia & $\begin{array}{l}\text { Felixstowe UD } \\
\text { Barnack RD }\end{array}$ & Scotland & $\begin{array}{l}\text { Edinburgh C of C } \\
\text { Glasgow C of C } \\
\text { Lanark SB } \\
\text { Withorn SB } \\
\text { Central LD }\end{array}$ \\
\hline
\end{tabular}

MB, Metropolitan Borough; CB, City and Borough; UD, Urban District; RD, Rural District; LB, London Borough; C of C, County of the City; SB, Scottish Burgh; LD, Landward Division.

* The names and boundaries of a number of these local authorites were changed in England in 1974 and in Scotland in 1975 under the Local Government Act (1972). The survey sample was drawn using electoral registers of the old authorities and the names and designations of these authorities are given.

sub-divided into high and low employment areas; other urban areas were divided according to whether their population was more or less than 75000 ; and rural areas were divided into high and low-density population areas. Within each stratum the areas were arranged in descending order using a socio-economic index. By interval sampling, fifty areas were then selected from these strata with probabilities proportional to their electorate, and their locations are listed in Table $\mathrm{I}$. Within each area two polling districts were selected at random, one to be surveyed in the summer and the other for the winter sample. In each polling district ten addresses were finally drawn at random from the electoral register, giving a total 1000 addresses, 500 for each survey period.

\section{The survey}

Households were invited to participate by an introductory letter from the Ministry. The interviewer then explained that the survey required the retention of all potentially edible food which would otherwise have been discarded during I week, and the keeping of a simple 
Table 2. Definition of income groups (gross weekly income of head of household)

\begin{tabular}{|c|c|c|}
\hline Income group & $\begin{array}{l}\text { Summer } \\
\text { (June-July 1976*) }\end{array}$ & $\begin{array}{l}\text { Winter } \\
\text { (February-March } 1977^{\dagger} \text { ) }\end{array}$ \\
\hline $\begin{array}{l}\text { AI } \\
\text { A2 } \\
\text { B } \\
\text { C } \\
\text { D } \\
\text { OAP }\end{array}$ & \multicolumn{2}{|c|}{$\begin{array}{l}\text { Old age pensioner households are those in which at least } \\
\text { three-quarters of total income is derived from }(a) \text { National } \\
\text { Insurance retirement or similar pensions or }(b) \text { supple- } \\
\text { mentary pensions or allowances paid in supplementation or } \\
\text { instead of pensions, or from both } a \text { and } b \text {. Such households } \\
\text { will include at least one person over the national insurance } \\
\text { retirement age. }\end{array}$} \\
\hline
\end{tabular}

diary of the main foods eaten by the family at each meal. The age and sex of each member of the household was recorded and the income group of the head of the household was determined, sometimes by the respondent indicating in which of a set of pre-selected ranges the gross weekly income would normally lie (Table 2). As an inducement or compensation to the participants, a small cookery book was given to everyone who agreed to undertake the survey.

We tried to collect all the potentially edible food which would normally have been discarded. This included plate waste, spilled food, leftovers in cooking and serving vessels, and meat and fat drippings which were not to be eaten later. It also included sour milk, stale bread and burnt toast, and fruit and vegetables which had become unfit to eat. Food which was regarded as inedible and was therefore not collected included outer leaves of green vegetables, potato peelings, apple cores, orange and banana skins, coffee grounds and tea 'dregs'. Meat bones and chicken carcasses were collected, however, and any adhering meat later recovered before the bones were finally discarded. Some foods were deliberately excluded from the study; these were soft drinks, alcoholic beverages and chocolate and sugar confectionery, as well as all meals and snacks eaten outside the home except that wastage from packed lunches and picnic-type meals derived from household supplies was included. This was to conform with National Food Survey (NFS) methodology so that reasonable comparisons could be made later between the survey results and 'expected' energy intakes (see p. 57).

It was recognized that this survey could influence the amounts and types of food wasted in some of the participating households. To minimize this, however, the interviewers did not emphasize the collection of waste food. Instead, they explained to each housewife that the survey was designed to obtain accurate information about the ways in which food is used and about the amounts and types of food which come into the home but are not eaten by the members of the household. It was gently suggested that wastage of some food would be inevitable and that it occurred in almost all households. The collection and storage procedures were then introduced to the housewife in this context.

Containers were provided for the daily, separate collection and storage of (1) meat, (2) fat, (3) potato, (4) cereals including bread, (5) milk, and (6) 'all other' food wastage (which may also have included items from any or all the other categories). Each household was provided with three large plastic containers, fifty small sealable plastic bags, ten plastic 
tubs for storing liquids, six large plastic bags, one roll of adhesive tape and one large carrier bag. All discarded food items were placed after each meal into appropriate containers, which had been colour-coded and labelled for the six types of food waste and numbered before allocation to the household. Bags were then sealed and placed in the larger containers. Liquid waste was poured into the tubs (after cooling, if necessary) which were then sealed at the end of the day and placed in the large containers, which were also sealed when full and stored. Exceptionally-large items were stored in the larger plastic bags and then in the carrier bag. This system of collection and storage kept all the waste in a tidy and unobtrusive manner, and reduced to the minimum for the housewife the unpleasantness of handling it. At the end of the week the containers were packed and sent to the Laboratory of the Government Chemist for analysis (see p. 58). The system proved satisfactory except in the instance of liquid wastes: some tubs proved difficult to seal completely and there was an unquantifiable amount of leakage, particularly of sour milk, in a number of instances.

Families which gave otherwise edible food to pets or which gave bread or other foods to wild birds were allowed to continue, but were asked to record as accurately as possible the amounts and types of food used in this way. It was emphasized that table scraps should be included in this category but not commercial pet foods. The composition of the food given to these animals was calculated from standard tables of food composition (Paul \& Southgate, 1978).

Finally, we wanted to know not only how much food was wasted but also what proportion this represented of the food used during the week (i.e. of the food taken from the domestic supplies for cooking or eating). But in both preliminary surveys (Dowler, r 977 ; Wenlock \& Buss, 1977), housewives found that the additional work involved in recording the types and amounts of all the foods used was very troublesome. Therefore, to avoid the possibility that this would reduce the response rate in the present national survey, we decided instead to relate the energy content of the food wasted to an 'expected' energy intake for each category of household, derived from comparable NFS records. During the restricted periods covered by our survey, however, the NFS samples for some of the household composition and income groups were so small that their recorded intakes of food energy were unlikely to be sufficiently reliable for this purpose. We therefore obtained more representative estimates by adjusting national average intakes during the periods under study to allow for family composition and income effects, as follows:

'expected energy intake (/household per week) = NFS national average intake (/person per $d$ ) for the period $\times$ number of people in the household $\times 7$ (d) $\times$ household factor.

The NFS national average intake was $9.5 \mathrm{MJ}(2270 \mathrm{kcal})$ in June-July 1976 and 9.3 MJ (2220 kcal) in February-March 1977. The household factors were obtained for households in almost all income and family composition groups by dividing the energy intakes recorded for those categories of household in the NFS in 1973, 1974 and 1975 (Ministry of Agriculture, Fisheries and Food, 1977) by the national average energy intakes in the same years. (After allowance for household composition and income group differences there are only minimal geographical variations in energy intake, so it was not necessary to introduce differential regional factors.)

To increase the validity of this approach, our survey was designed to follow NFS methodology wherever possible (Appendix A, Ministry of Agriculture, Fisheries and Food, 1978a). 


\section{Analytical methods}

All analyses were carried out at the Laboratory of the Government Chemist in London, where the summer samples were stored in a freezer and the winter samples were kept in a cold room at $4^{\circ}$ until preparation. At this stage, any remaining inedible matter (bones, peel and packaging) was removed and each sample was then weighed and homogenized. For 'fat' samples which were not wet, a representative portion of up to $30 \mathrm{~g}$ was stored in a refrigerator. In all other instances up to $100 \mathrm{~g}$ were freeze-dried, except for bread which was air-dried. Dried samples were ground and stored under air-tight conditions. Energy contents were measured by ballistic bomb calorimetry (Gallenkamp, Technico House, Christopher Street, London), readings being taken from the galvanometer after $3 \mathrm{~min}$. For all samples except fat, $0.5 \mathrm{~g}$ was taken. For fats $0.3 \mathrm{~g}$ was taken, together with $0 . \mathrm{Ig}$ benzoic acid which was necessary to obtain satisfactory ignition; a correction for the exact weight of benzoic acid used was then applied. A few samples did not freeze-dry properly and gave lower energy values than expected, so were re-dried and re-analysed. Investigation of twelve samples which differed only in their moisture content up to a maximum of $60 \%$ water showed that, provided the moisture content did not exceed $40 \%$, the energy value calculated on a dry basis was constant. If, however, the sample contained more than $40 \%$ moisture results were erratic because of incomplete combustion.

In addition, the fat content of all the meat samples was determined by a standard analytical technique (British Standards Institution, 1970).

\section{Statistical methodology}

The relationships between the various measures of wastage and the region, income group and composition of the households were investigated by regression analysis. The same form of model was used in all the analyses referred to below: each dependent variable (e.g. energy content of waste, energy content of waste as a percentage of 'expected' intake) was regressed upon a simple linear function of the number of adults in the household, the number of children (defined as persons less than 18 years old) in the household, a measure of the number of meals eaten outside the home by household members during the survey, and dummy variables (Goldberger, I974) representing the region in which the household was located and the income group of the head of the household. Where the information obtained from the two sampling periods was combined, a further dummy variable was introduced to represent the possible difference between the levels of wastage in the two rounds after the other factors fitted in the regression (e.g. region, number of adults) had been taken into account. The model assumes that the effects on food waste (however defined) of each of the factors under investigation are simply additive.

\section{RESULTS AND DISCUSSION}

In the summer, $338(68 \%)$ of the households asked to participate co-operated fully, and $334(67 \%)$ took part in the following winter.

\section{Sample structures}

The compositions of the two samples are compared in Table 3, and for further comparison the composition of the National Food Survey sample in 1976 (Ministry of Agriculture, Fishereies and Food, 1977) is also shown. There were no significant differences between the summer and winter samples in the wastage study with respect to regional distribution or family composition, but the distribution of households between the income groups was significantly different in the two rounds $\left(\chi^{2}, P<0.01\right)$ with fewer households with higher incomes in the winter sample. This may have arisen simply because in the NFS the income ranges are defined with the intention of producing fixed percentages of households in each 
Table 3. Structure of the survey sample, and of National Food Survey (Ministry of Agriculture, Fisheries and Food, 1977) (NFS) sample for comparison

(a) Region
England
North
Yorkshire and
Humberside
North West
East Midlands
West Midlands
South West
South East excluding
Greater London
East Anglia
Greater London
Wales
Scotland
Total

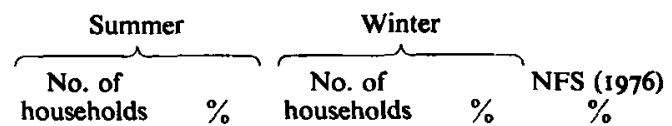

(b) Income of the head of household

$\begin{array}{lrrrrr}\text { A1 } & 12 & 3.6 & 6 & 1 \cdot 8 & 4.1 \\ \text { A2 } & 23 & 6.8 & 9 & 2 \cdot 7 & 7 \cdot 0 \\ \text { B } & 65 & 19.2 & 44 & 13.2 & 34.8 \\ \text { C } & 85 & 25 \cdot 1 & 112 & 33.5 & 26.5 \\ \text { D } & 38 & 11 \cdot 2 & 45 & 13.5 & 4 \cdot 1 \\ \text { OAP } & 63 & 18.6 & 69 & 20.7 & 14.1 \\ \text { Don't know } & 33 & 9.8 & 35 & 10.5 & - \\ \text { Refused } & 19 & 5 \cdot 6 & 14 & 4 \cdot 2 & - \\ \text { Total } & 338 & 100 & 334 & 100 & 90.6^{*}\end{array}$

(c) No. of persons

$\left.\begin{array}{rrrrrr}1 & 46 & 13.6 & 48 & 14.4 & 16.5 \dagger \\ 2 & 112 & 33.1 & 114 & 34.1 & 32.5 \\ 3 & 60 & 17.8 & 61 & 18.3 & 17.7 \\ 4 & 63 & 18.6 & 66 & 19.8 & 20.5 \\ 5 & 39 & 11.5 & 24 & 7.2 & 8 \cdot 1 \\ 6 & 12 & 3.6 & 10 & 3.0 & 3.4 \\ 7 & 5 & 1.4 & 6 & 1.8 & 0.9 \\ 8 & 1 & 0.3 & 2 & 0.6 \\ 9 & - & - & 2 & 0.6 \\ 14 & - & - & 1 & 0.3\end{array}\right\}$

(d) No. of adults

\begin{tabular}{|c|c|c|c|c|c|}
\hline I & 56 & 16.6 & 56 & 16.7 & 18.54 \\
\hline 2 & 220 & 65.1 & 213 & 63.8 & $63.1 t$ \\
\hline 3 & 50 & $14-8$ & 48 & 14.4 & 14.35 \\
\hline 4 & 11 & $3 \cdot 3$ & 14 & $4 \cdot 2$ & $3.4 \dagger$ \\
\hline 5 & $\mathbf{I}$ & 0.3 & I & 0.37 & \\
\hline 7 & - & - & I & 0.3 & $0.7 \dagger$ \\
\hline 10 & - & - & I & 0.3 & \\
\hline Total & 338 & 100 & 334 & 100 & 100 \\
\hline
\end{tabular}

(e) No. of children

$\begin{array}{crrrrr}0 & 195 & 57 \cdot 7 & 193 & 57.8 & 57 \cdot 3 \dagger \\ 1 & 33 & 9 \cdot 8 & 46 & 13.8 & 15.3 \dagger \\ 2 & 64 & 18.9 & 61 & 18.3 & 18.0 \dagger \\ 3 & 32 & 9 \cdot 5 & 20 & 6.0 & 6.5 \dagger \\ 4 & 10 & 3 \cdot 0 & 10 & 3.0 & 2.0 \dagger \\ 5 & 4 & 1 \cdot 2 & 3 & 0.9 & 0.6 \dagger \\ 6 & -1 & 1 & 0.3 & 0.3 \dagger \\ \text { Total } & 338 & 100 & 334 & 100 & 100\end{array}$

* $9.4 \%$ of households reported no earned income, but no distinction was made between earned and unearned income in our survey.

+ Derived from 2608 households participating during June-July 1976 and February-March 1977, compared with regional and income distributions from 7516 households during the whole of 1976 . 

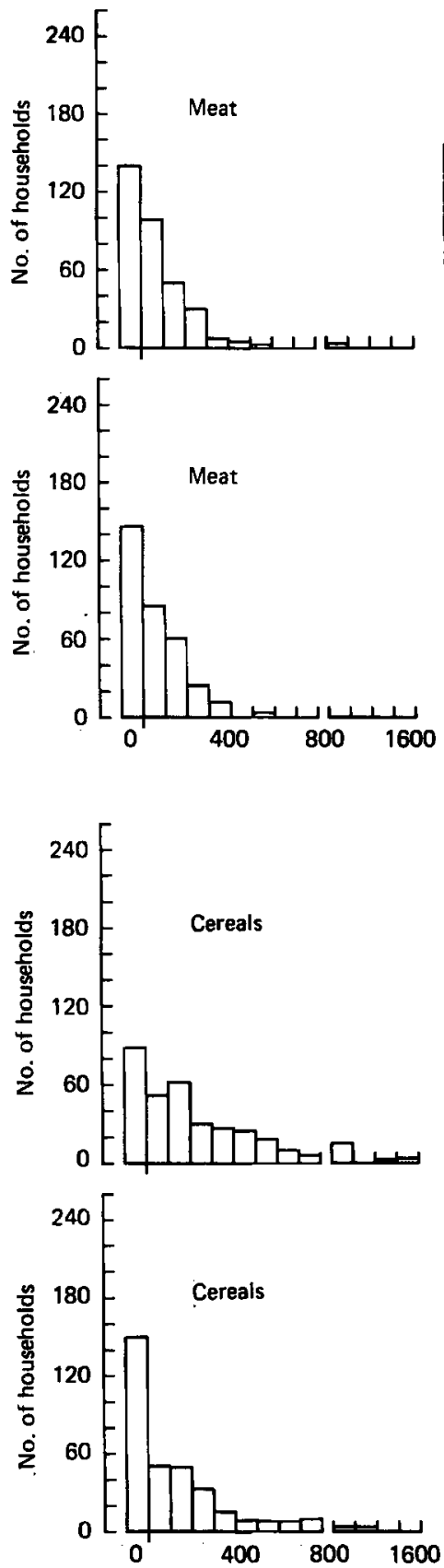

(a)
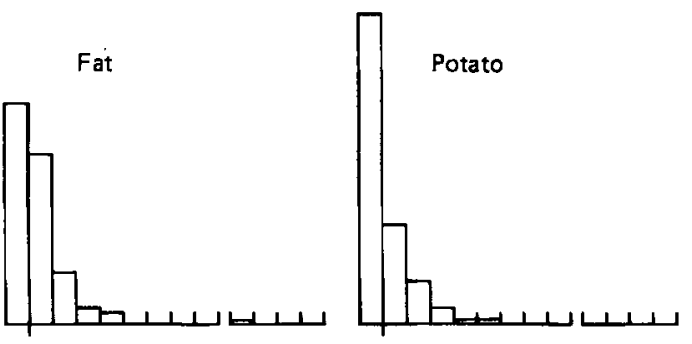

(b)
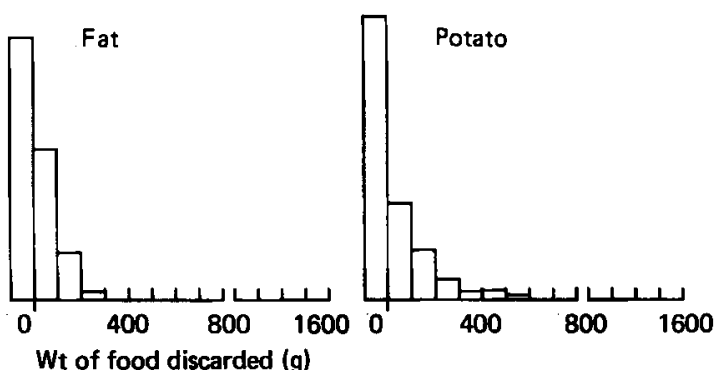

(a)

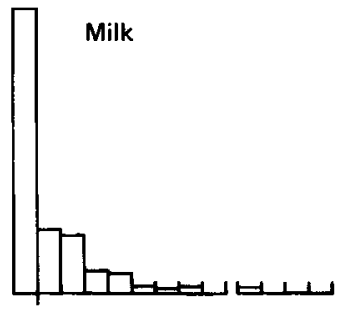

Other food

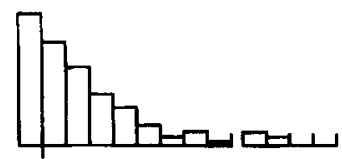

(b)

Milk

Other food

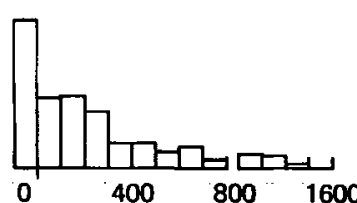

Fig. I. Weights of each category of wasted food, as collected from (a) 338 households in the summer and $(b) 334$ households in the winter throughout Britain ( $\mathrm{g} /$ household per week).

group over I year; consequently, when money incomes are rising through a period of time there will always be relatively few households in the higher income groups early in the year (February-March) and relatively more later in the year (June-July). 
Table 4. Composition of waste food collected

$\overbrace{\text { Mean }}^{\text {SE }} \underbrace{\text { Summer }}_{\text {Range } \% \text { total }} \overbrace{\text { Mean }}^{\text {SE }} \underbrace{\text { Winter }}_{\text {Range } \% \text { total }}$

(a) By wet weight ( $\mathrm{g} / \mathrm{household} \mathrm{per} \mathrm{week)}$

$\begin{array}{lrrrrrrrr}\text { Meat } & 89 & 8 & 0-980 & 12 \cdot 1 & 82 & 7 & 0-810 & 13 \cdot 9 \\ \text { Fat } & 55 & 6 & 0-880 & 7 \cdot 5 & 36 & 4 & 0-630 & 6 \cdot 1 \\ \text { Potato } & 41 & 5 & 0-810 & 5.6 & 57 & 6 & 0-530 & 9 \cdot 6 \\ \text { Cereals } & 245 & 16 & 0-1820 & 33 \cdot 2 & 146 & 12 & 0-1210 & 24 \cdot 7 \\ \text { Milk } & 93^{*} & 12 & 0-2760 & 12.6 & 36 & 5 & 0-920 & 6 \cdot 1 \\ \text { Othert } & 215 & 18 & 0-2850 & 29 \cdot 1 & 235 & 17 & 0-2300 & 39 \cdot 8 \\ \text { Total } & 738 & 43 & 0-7830 & 100 & 591 & 33 & 0-3390 & 100\end{array}$

(b) By energy content (MJ/household per week)

\begin{tabular}{|c|c|c|c|c|c|c|c|c|}
\hline Meat & 1.6 & 0.13 & $0-17 \cdot 6$ & 16.7 & $1 \cdot 5$ & 0.13 & $0-21 \cdot I$ & $20 \cdot 7$ \\
\hline Fat & $2 \cdot 0$ & 0.20 & $0-36.6$ & $21 \cdot 7$ & $1 \cdot 4$ & 0.15 & $0-23.6$ & $19 \cdot 7$ \\
\hline Potato & 0.2 & 0.03 & $0-5.4$ & $2 \cdot 3$ & 0.3 & 0.03 & $0-44$ & 4.5 \\
\hline Cereals & $3 \cdot 7$ & 0.24 & $0-26.4$ & $39 \cdot 4$ & $2 \cdot 2$ & 0.18 & $0-18.5$ & $30 \cdot 6$ \\
\hline Milk & $0.3^{*}$ & 0.04 & $0-8.6$ & $3 \cdot 5$ & 0.2 & 0.02 & $0-3.1$ & $2 \cdot 1$ \\
\hline Othert & 1.5 & 0.16 & $0-27.5$ & 16.4 & 1.6 & 0.13 & $0-23.4$ & $22 \cdot 4$ \\
\hline Total & $9 \cdot 3$ & 0.50 & $0-65.7$ & 100 & $7 \cdot 1$ & 0.38 & $0-37 \cdot 0$ & 100 \\
\hline
\end{tabular}

(c) By energy density ( $\mathrm{kJ} / \mathrm{g})$

$\begin{array}{llll}\text { Mean } & \text { SE } & \text { Mean } & \text { SE } \\ 12.60 & 0.33 & 12.03 & 0.25\end{array}$

* This underestimates milk waste because of spillage from some containers.

$\dagger$ Includes all food not separated into discrete categories. It may therefore include some foods from other groups.

The number of persons per household averaged 2.99 in the summer sample, 2.97 in the winter, and 2.92 in the NFS.

\section{Composition and energy content of food waste collected}

For each household, we obtained a record of the weight and energy content of the food discarded in each of six categories (meat including meat fat, other fat, potato, cereals, milk and all other), the energy content of the food (if any) estimated to have been fed to pets and birds, and therefore the total amount of food 'wasted'.

The characteristics of the food discarded (i.e. that which we collected from the housewives) are summarized for the entire sample in Table 4. Variation in this form of wastage was very high and it was quite common for little or no food to be discarded in any of the six categories by some households; in both sampling periods the distributions were therefore highly skewed towards zero in every food category, as shown in Fig. I.

Both in summer and in winter, bread and other cereal products predominated in the food collected, particularly in terms of energy (approximately 40 and $30 \%$ of the totals in the two rounds). Meat, fat, and the miscellaneous categories were also important sources of wasted energy. In terms of wet weight, however, wasted milk became more important, especially in the summer (12.6\% of the total weight of food collected) and the relative contributions of potato and the miscellaneous category also increased while those of meat and especially fat decreased (Table 4). Over all, the total quantity of food which was discarded was higher in summer than in the winter, averaging $738 \mathrm{~g}$ or $9.3 \mathrm{MJ}(2220 \mathrm{kcal}) /$ household per week and 59I $\mathrm{g}$ or 7. I MJ (I700 kcal)/household per week respectively. Regression 
Table 5. Energy content (MJ/household per week) of food fed to pets and wild birds

\begin{tabular}{|c|c|c|c|c|c|c|c|c|}
\hline & \multicolumn{4}{|c|}{ Summer } & \multicolumn{4}{|c|}{ Winter } \\
\hline & $\begin{array}{l}\text { No. of } \\
\text { households }\end{array}$ & Mean & SE & Range & $\begin{array}{c}\text { No. of } \\
\text { households }\end{array}$ & Mean & SE & Range \\
\hline $\begin{array}{l}\text { In households which } \\
\text { fed animals }\end{array}$ & 87 & $9 \cdot 2$ & $1 \cdot 0$ & $0-43.5$ & I 57 & $6 \cdot 3$ & 0.5 & $0-99.6$ \\
\hline $\begin{array}{l}\text { Averaged over all } \\
\text { households }\end{array}$ & 338 & $2 \cdot 4$ & 0.4 & $0-43.5$ & 334 & $3 \cdot 0$ & 0.5 & $0-99.6$ \\
\hline
\end{tabular}

analysis indicated that, had other factors been equal in the two rounds, this would have been a difference of $136 \mathrm{~g}$ or $2 . \mathrm{I} \mathrm{MJ}(500 \mathrm{kcal}) /$ household per week; these differences were statistically significant $(P<0.01)$.

In addition to the separated fat, the mean fat content of the meat collected was equivalent to $24 \mathrm{~g}$ /household in both rounds, or approximately $28 \%$ of the weight of the meat. Altogether, fat therefore contributed 31 and $32 \%$ of all the energy discarded in the summer and winter respectively, and there would also have been a small amount of fat in some of the other food groups; in contrast, $70-80 \%$ of the energy wasted in America was from fat (Adelson et al. I963).

\section{Food fed to pets or wild birds}

The food energy estimated to have been fed to pets and wild birds is summarized in Table 5 . Potentially-edible foods were used in this way in eighty-seven households ( $26 \%$ of the total) in the summer and 157 households $(47 \%)$ in the winter, much of the difference being due to the greater number of households feeding birds in the winter. In the households which gave food to pets and birds, the energy content of the food used in this way averaged $9.2 \mathrm{MJ}$ $(2200 \mathrm{kcal}) /$ week in the summer and $6.3 \mathrm{MJ}$ ( $1500 \mathrm{kcal}) /$ week in the winter, which is equivalent to $52 \%$ and $46 \%$ of the total food wasted by such households in the summer and winter respectively. Thus, households feeding animals wasted on average a total of $17.7 \mathrm{MJ}$ $(4240 \mathrm{kcal}) /$ week in the summer and $13.6 \mathrm{MJ}(3250 \mathrm{kcal}) /$ week in the winter. In contrast, all other households recorded an average total wastage of $9.5 \mathrm{MJ}(2280 \mathrm{kcal}) /$ week in summer and 6.9 MJ (1660 kcal)/week in winter, approximately half as much in each round as households feeding pets. The difference between the averages for these two groups of households is therefore almost entirely due to the quantities of food fed to animals.

Food given to animals was particularly important in some households, with six households in each round using more than $4.2 \mathrm{MJ}$ ( $1000 \mathrm{kcal}$ ) $/ \mathrm{d}$ in this way during the week. In ten of these households large quantities of meat were given to dogs and in the other two up to ten loaves of bread were given to horses. It is therefore probable that these households purchased the meat and the bread especially for this purpose although it was not possible from the information collected to ascertain for any household what proportion of the food given to pets had been purchased with this end in mind and what proportion was simply scraps.

When averaged across all the households, food given to pets amounted to only $2.4 \mathrm{MJ}$ $(570 \mathrm{kcal}) /$ week in the summer and $3.0 \mathrm{MJ}$ (710 kcal)/week in the winter. This difference between the two sampling periods is not statistically significant. These values must be minimum estimates since seventeen households $(5 \%)$ in the summer and twenty-four households $(7 \%)$ in the winter said that they gave unquantifiable amounts of scraps to pets or wild birds during the survey week. Nevertheless, food given to animals still amounted to 
approximately $20 \%$ of the total waste recorded during the summer and approximately $30 \%$ of that recorded during the winter by our entire sample.

Analysis of the energy content of food given to animals yielded no statistically-significant relationships between this aspect of waste and family composition, income or region but the enormous variability in the results may have obscured any relationships which did exist. However, as the quantity of food wasted in this way by individual households depended almost entirely upon whether or not a pet was present, any relationship which had been observed would to a large extent have simply reflected patterns in pet ownership.

\section{Energy content of all food uneaten, both in absolute terms and in relation to 'expected' household intake}

The sum of the food which was collected and that which was given to pets represents the total wastage of potentially-edible food. The combined energy content was equivalent to II.7 MJ $(2790 \mathrm{kcal}) /$ household per week in the summer and I0.I $\mathrm{MJ}(2410 \mathrm{kcal}) /$ household per week in the winter. The large variations in the amounts of food given to animals, however, resulted in estimated standard errors for total wastage of $0.6 \mathrm{MJ}$ in each sampling period. This seasonal difference therefore failed to reach formal significance, in contrast to that for the food which was actually discarded.

This total wastage (i.e. including the food given to animals) was also compared with the 'expected' energy intake of the households as described previously (p. 57). Averaged over the whole sample it represented $6.5 \%$ of the food intake in the summer and $5.4 \%$ in the winter, this difference being significant $(P<0.05)$. When the effects of the slightly different regional, income and household composition distributions had been removed by the standard regression analysis, the seasonal difference became $\mathrm{I} \cdot 2 \%$. This too was statistically significant $(P<0.05)$, confirming that the households in our survey did indeed waste more of their potential food resources in the summer than in the winter. Although we recognize that the expected intakes which were used can only be approximations to the average energy intakes of the household categories in this survey, the similarity of our sample to that of the NFS suggested that they were sufficiently accurate for the purpose in hand.

In each of the subsequent analyses of the influence of region, income group and family composition upon wastage, we were most concerned about their effects upon the total food which was not eaten because this will have the greatest relationship with total household demand for food. Nevertheless, each aspect of wastage is shown separately for each type of household in Tables 6-10, and these are discussed in the remainder of this paper. All regression analyses were performed separately for the summer and winter samples because of the apparent differences between them.

\section{Effect of household composition on wastage}

The total amount of food wasted in a household was markedly dependent upon the composition of the family. Table 6 shows the relationships between the total number of people present and the four different aspects of wasted food which we studied, i.e. (r) the energy content of the food collected, (2) the energy content of the food estimated to have been given to pets and wild birds, (3) the sum of these (each expressed in MJ/household per week) and (4) this total as a percentage of the energy content of the food expected to have been brought into each kind of household. Tables 7 and 8 show similar relationships between wastage and the number of adults and the number of children present.

Number of people. As might be expected, the absolute amount of food collected increased significantly with the number of people present, both in summer $(P<0.01)$ and in winter $(P<0.01)$ (Table 6). This relationship appeared to be biphasic, however, for wastage per household increased until there were from four to six people in the family and then tended 

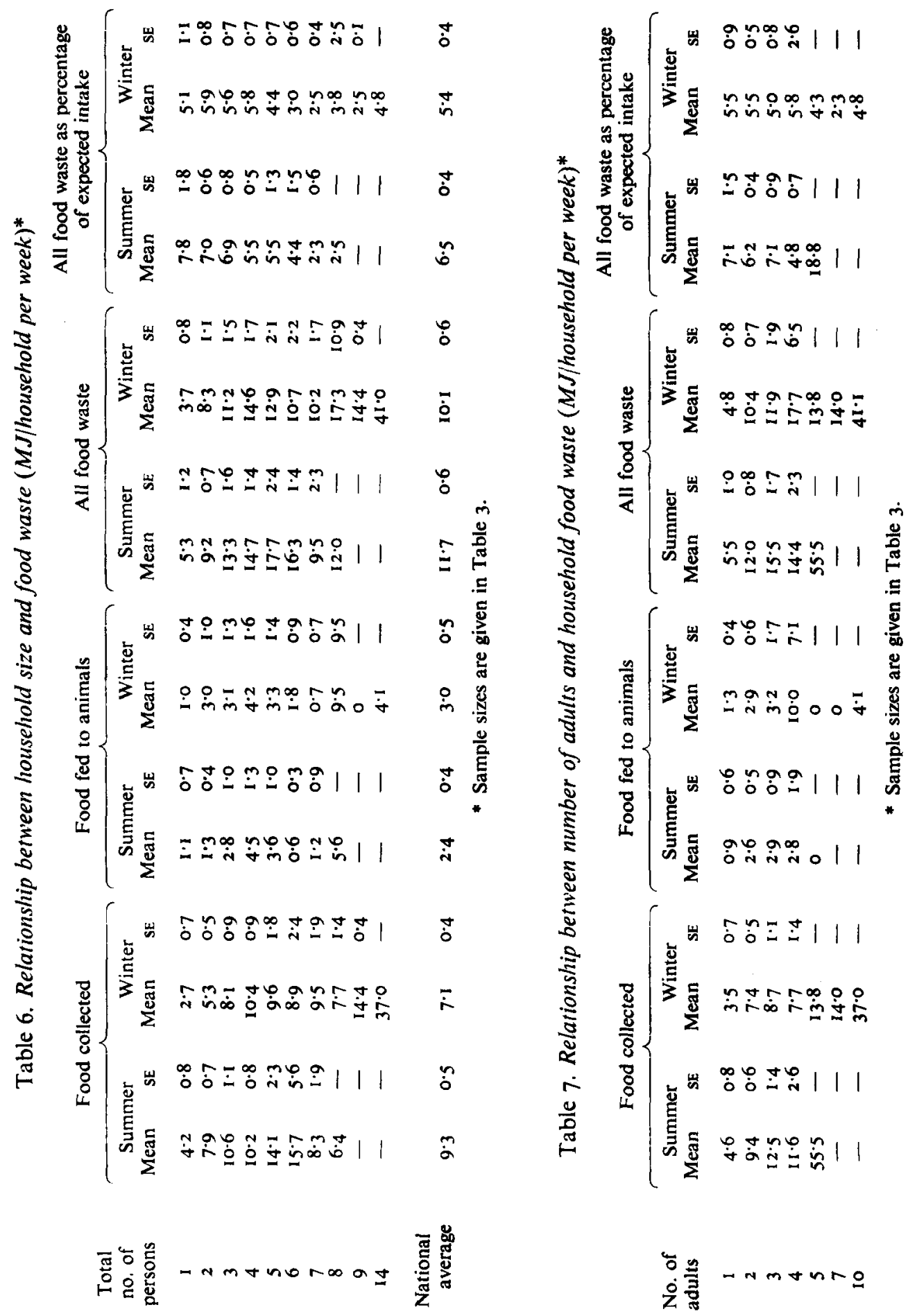

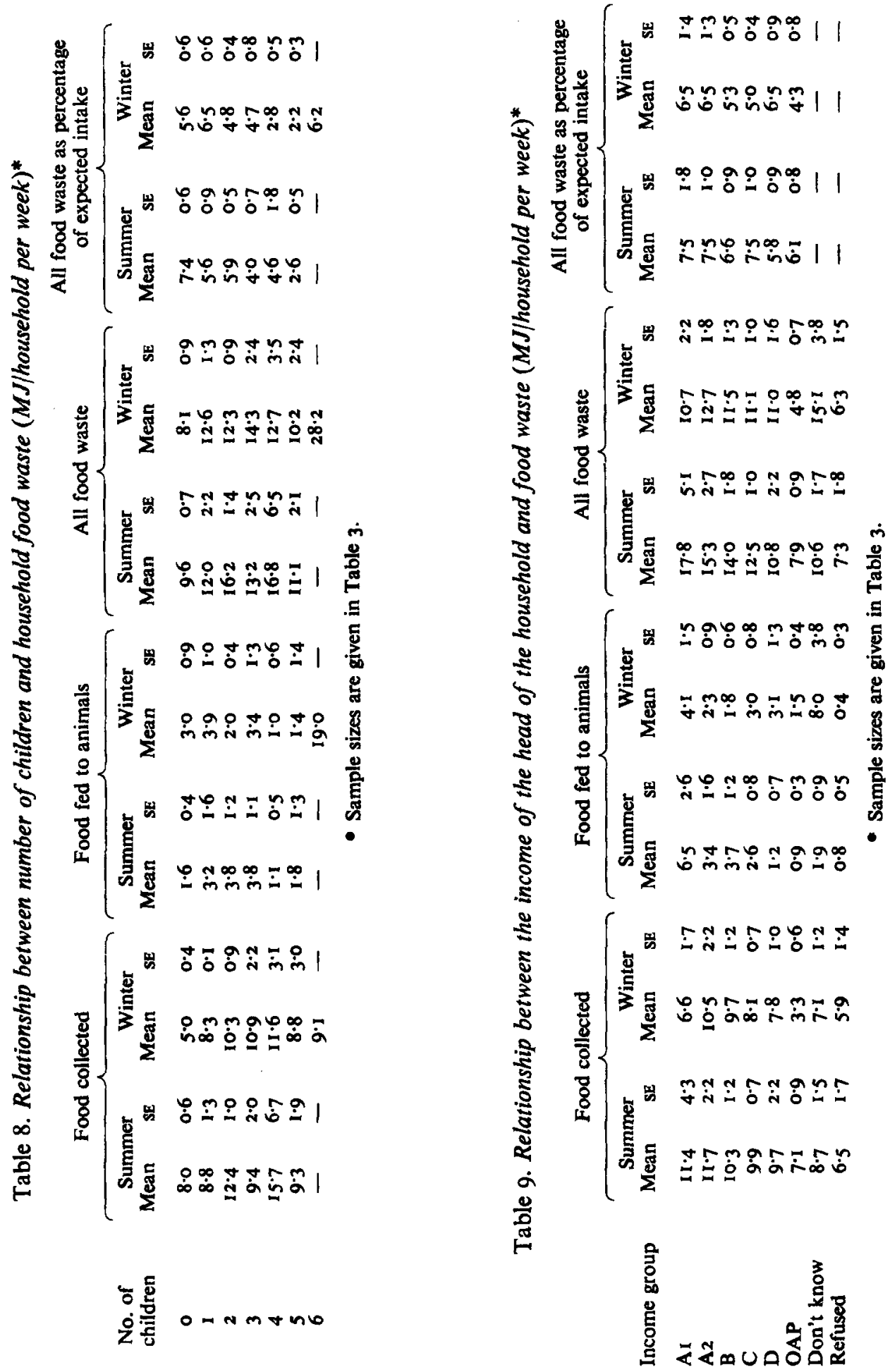
to decrease again. As larger families almost invariably contain children, the separate effects of adults and children on food wastage were then examined in turn, and regression analysis found that the effects of the two upon wastage were significantly different.

Number of adults. The number of adults was a significant factor in raising the energy content of the food discarded both in summer and winter, with regression coefficients of 4. I MJ (990 kcal) and I.6 MJ (370 kcal) /week respectively (Table 7). These coefficients may be interpreted as the average amounts of energy discarded from a household by each adult. The energy content of all food wasted, including that fed to pets and birds, was also significantly increased by the presence of additional adults, the regression coefficients becoming $4.4 \mathrm{MJ}$ (1060 kcal) and $2.7 \mathrm{MJ}(640 \mathrm{kcal}) /$ week in summer and winter $(P<0.01$ in every case). However, for food wastage expressed as proportion of expected food intakes, there was no significant relationship with the number of adults in the household probably because additional wastage would have been matched by a corresponding increase in the food bought.

Number of children. The number of children was also a significant determinant of the energy content of waste food collected in each round, but with regression coefficients of only I.0 MJ $(250 \mathrm{kcal}) /$ week in the summer $(P<0.0 \mathrm{I})$ and $\mathrm{I} \cdot 3 \mathrm{MJ}(320 \mathrm{kcal}) /$ week in the winter $(P<0.01)$ (Table 8$)$. Each additional child also significantly increased the total amount of food wasted (i.e. including that fed to animals) in the summer, with a regression coefficient of $\mathrm{I} .6 \mathrm{MJ}(380 \mathrm{kcal}) /$ week $(P<0.0 \mathrm{I})$, but in the winter this relationship did not reach formal significance. In contrast, the percentage of the expected energy intake which was wasted was inversely related to the number of children in the family, i.e. as the number of children increased, the proportion of the family's food resources that was wasted decreased. The regression coefficients were $-1.3 \%$ in both seasons, but only in the summer was this formally significant $(P<0.01)$. Table 8 also indicates (not unexpectedly) that, ignoring other socio-economic factors, the first child was associated with the highest additional energy loss in the winter and that each successive child added less waste to the household total than did the previous one.

\section{Influence of income on wastage}

The relationships between food wastage and the income of the head of the household are shown in Table 9. In the summer, there was a clear relationship between wastage and income, for the highest income groups not only tended to discard most food but also fed more to pets, while pensioner households wasted the least. In winter, however, income groups AI discarded less than groups A2-D although they still gave most food to pets, and pensioner households again wasted the least (in part because they contained fewer people). Over all, this wastage represented $7 \%$ of the food likely to have been used in groups AI and A2 but approximately $5 \%$ in pensioner households. Nevertheless, the relationships between income and wastage did not reach formal significance after the effects due to differences in household size and region had been removed using the standard regression technique.

\section{Geographical differences in wastage}

The amounts of food wasted in each of the standard regions of Britain are summarized in Table I0. Over all, wastage appeared highest in Greater London and East Anglia, the West Midlands and the North West of England, and lowest in Wales, Yorkshire and Humberside and the East Midlands, but these differences were not statistically significant. In the summer, however, the amount of food returned to us from South-East England (excluding Greater London) was significantly less than from the other regions $(P<0.5)$; this was because more than $22 \%$ of these households discarded no food at all whereas elsewhere only $10 \%$ on average discarded nothing. In contrast most food was returned to us from nearby London and East Anglia. Some food which might otherwise have been discarded could, however, 

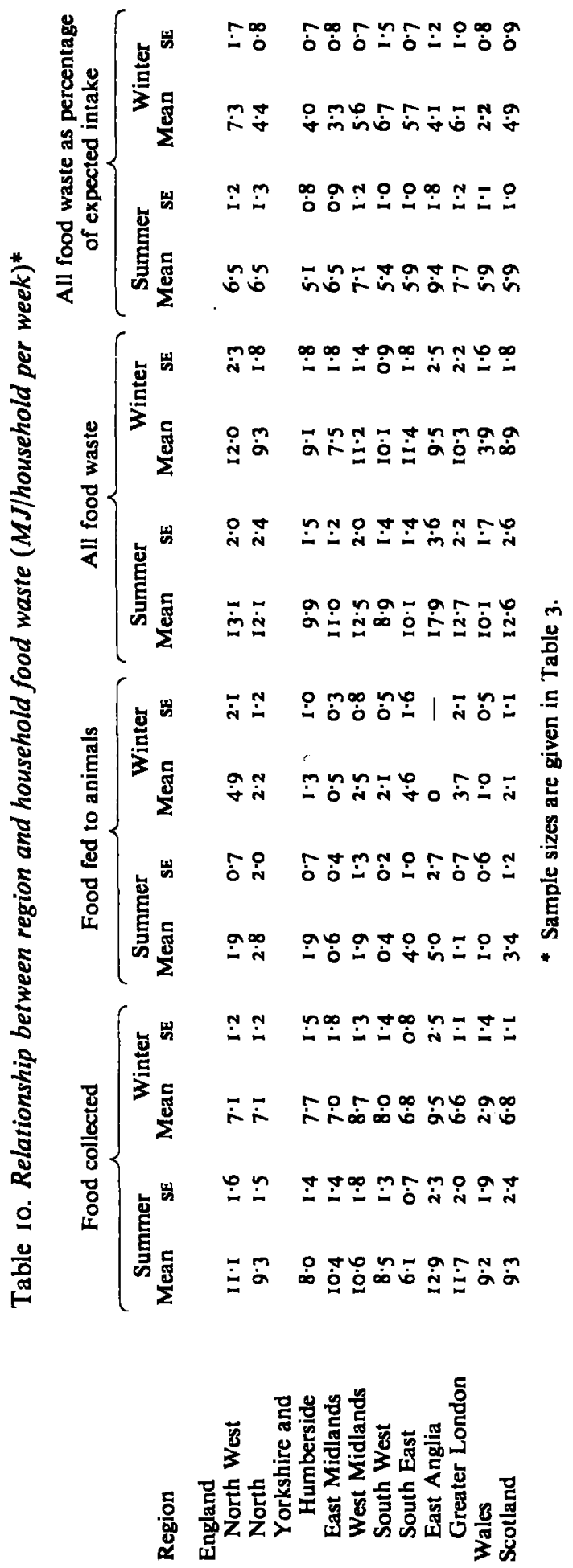
have been given to pets and wild birds, for there was a tendency for such feeding to be highest in regions which returned the least food to us. The most notable exceptions were in East Anglia in the summer, when both forms of wastage were high, and in Wales in the winter when both were low. These extremes represented 9.4 and $2.2 \%$ of the expected intake respectively.

\section{CONCLUSIONS}

This nationwide investigation extends the preliminary work of Dowler (1977) and Wenlock \& Buss (1977) who studied food wastage only in small numbers of households in London and South-East England. It demonstrated that, of the edible portion of the food brought into the home, an average of $6.5 \%$ remained uneaten in the summer and $5.4 \%$ in the winter. This was equivalent to I $1 \cdot 7 \mathrm{MJ}$ (2790 kcal) and I0. I MJ (24I0 kcal)/household per week in the two seasons respectively, or approximately $0.6 \mathrm{MJ}$ (I50 kcal) and $0.5 \mathrm{MJ}$ ( $130 \mathrm{kcal}$ )/person per d. Domestic wastage thus appears to account for less than one-quarter of the total gap between the total food supplies in the United Kingdom and the food thought to be eaten (as represented by recommended energy intakes; Department of Health and Social Security, 1969). Nevertheless, although similar values were obtained by Dowler (1977) and Wenlock \& Buss (1977), this type of study is likely to under-estimate domestic food wastage somewhat, for, despite all our precautions, any modification of housewives' normal food usage patterns during the week of the survey would be more likely to result in decreases than in increases in their food wastage (Adelson et al. 1961 ; Adelson et al. 1963). Further, no matter how diligent the interviewers, errors will occur in recording and such errors are likely to be omissions. For example, housewives may forget to retain some food waste or to record some food fed to pets and may be unable to collect all food adhering to cooking vessels. On the other hand, the first half of our survey was conducted during the very hot summer of 1976 , and more food than normal could have been spoilt and discarded, especially in the $9 \%$ of homes without a refrigerator (Ministry of Agriculture, Fisheries and Food, 1977). It should also be noted that calorimetric estimations of food energy slightly over-estimate the metabolizable energy of the food.

Where households keep pets, particularly dogs, considerable quantities of food can be diverted to the animals. This was on average equivalent to $20 \%$ of all the food wasted in the summer, but in the winter, with increased losses of bread to wild birds and less food discarded this amount rose to almost $30 \%$. Apart from bread, meat of various kinds given to the dogs accounted for most of this form of wastage. In different groups of pet-owning households, between 6.3 and $9.2 \mathrm{MJ}$ (1500-2200 kcal)/week were estimated to have been given to animals which compares with the energy content of the food collected from these households of between $7 \cdot \mathrm{I}$ and $9 \cdot 3 \mathrm{MJ}$ (I 700-2220 kcal)/week. Pets therefore have a very important influence on the ultimate fate of food entering such households and also on the magnitude of their food wastage.

This nationwide survey also extends previous work by quantifying domestic food wastage in Britain according to the number of adults and children in the household, and with respect to income and geographical location. Yet the variations between households were so large that, even with a sample of nearly 700 households, few of the apparent differences reached formal significance. The main conclusion to emerge was that larger families wasted more food in total, but less in proportion to their expected energy intake. This is likely to be due to economies of scale in larger households. Separate analysis of the effects of children and adults showed, however, that there was a significant inverse relationship between the number of children and the proportion of the family's food resources that are wasted. Further, the first child appeared to add the most wastage (in the winter) with each additional child having less and less effect. In contrast, each adult in the family appeared to waste similar amounts 
of food: $4.4 \mathrm{MJ}$ (1060 kcal)/week in summer and $2 \cdot 7 \mathrm{MJ}(640 \mathrm{kcal}) /$ week in winter, equivalent to $0.6 \mathrm{MJ}(150 \mathrm{kcal}) / \mathrm{d}$ and $0.4 \mathrm{MJ}(90 \mathrm{kcal}) / \mathrm{d}$ respectively. The apparent efficiency of larger families in their food utilization is thus due more to those with additional children than to those with additional adults. This clarifies the position reported by Dowler (1977) and Wenlock \& Buss (1977) who only found a direct relationship with the number of people in the household, with each person contributing in effect approximately $0.4 \mathrm{MJ}$ $(95 \mathrm{kcal}) / \mathrm{d}$, or $6 \%$ of the mean per caput energy intake.

Wastage also tended to increase with increasing income, both in absolute terms and in relation to expected food intake, although the effects were not formally significant. Pensioner households appeared to waste the least, but such households normally contain comparatively few people; unfortunately, because of the different wastage associated with adults and with children, analyses of wastage per person in households with different incomes yielded no useful results.

Finally, although there are marked regional differences in the kinds of food purchased in Britain (Ministry of Agriculture, Fisheries and Food, 1977), there was only one significant regional departure from the mean quantity of food wasted. Households in South-East England discarded least food in the summer, perhaps because the amount of otherwise uneaten food which they gave to animals instead was higher than average. However, total food wastage in nearby East Anglia was higher than average, so there were no obvious geographical trends in food wastage.

Almost all these analyses of wasted food have been in terms of its energy content, and because of the variability of the results further analyses were not meaningful. In particular, variations in the weights of wasted meat, fat, potato, cereals, milk and other foods were so large that unfortunately no useful results were obtained when these were analysed by family size, income group or region.

The authors thank Paul Harrison, Erhard Meier and the staff of Research Services Limited who, after a pilot study, recruited all the households and collected and returned the wasted food. Without their expertise in household surveys, this study would have been impossible. They also thank Miss Jean Robertson who helped in the initiation of the survey and the staff of the Laboratory of the Government Chemist, who had to analyse some very unpleasant putrid and maggot-infested samples especially in the summer.

\section{REFERENCES}

Adelson, S. F., Asp, E. \& Noble, I. T. (196I). J. Am. Diet. Ass. 39, 578.

Adelson, S. F., Delaney, I., Miller, C. \& Noble, I. T. (1963). J. Home Econ. 55, 633.

British Standards Institution (1970). British Standard 440I, part 4, method A. London: British Standards Institution.

Cathcart, E. P. \& Murray, A. M. (1939). J. Hyg., Camb. 39, 45.

Department of Health and Social Security (1969). Rep. Publ. Hith. med. Subj. no. 120.

Department of Health and Social Security (1979). Rep. Hlth Soc. Subj. no. 15.

Dowler, E. A. (1977). J. hum. Nutr. 31, I7I.

FAO (1952). Second World Food Survey. Rome: FAO.

General Accounting Office (1977). Report to Congress by the Comptroller General of the United States, no. CED-77-1 18. Washington, DC: General Accounting Office.

Goldberger, A. S. (1974). Econometric Theory, p. 218. New York: John Wiley \& Sons.

Harrison, G. G., Rathje, W. L. \& Hughes, W. W. (1975). J. Nutr. Ed. 7, 13.

Hollingsworth, D. F. \& Baines, A. H. J. (1961). Family Living Studies, p. 120 . Geneva: International Labour Office.

Ministry of Agriculture, Fisheries and Food (1977). Household Food Consumption and Expenditure: 1975 and 1976. London: H.M. Stationery Office.

Ministry of Agriculture, Fisheries and Food (1978a). Household Food Consumption and Expenditure: 1977. London: H.M. Stationery Office.

Ministry of Agriculture, Fisheries and Food (1978b). Trade and Industry 32, 746. 
Paul, A. A. \& Southgate, D. A. T. (1978). McCance \& Widdowson's 'The Composition of Foods' 4th revised ed. London: H.M. Stationery Office.

Singer, D. D. \& Smart, G. A. (1978). Fd Drink Ind. Coun. Bull. 8, 17.

Wenlock, R. W. \& Buss, D. H. (1977). J. hum. Nutr. 31, 405. 